\title{
A Comparative Study of French, British, Dutch, and Russian External Supervisory Agencies of Investigators and Prosecutors within Integrated Criminal Justice System
}

\author{
Agus Budianto* \\ DOI: https://doi.org/10.22304/pjih.v5n3.a7
}

Submitted: November 1, 2018 | Accepted: December 28, 2018

\begin{abstract}
Criminal justice system consists of sub-systems that carry out different tasks and authorities. However, they have the same purpose to implement legal provisions against crimes. The sub-systems cover police, prosecutor, court, and correctional institution. However, in practice, especially in Indonesia, the relation of these sub-systems is not harmonious. It causes legal certainty becoming hard to achieve. One of the solutions is the establishment of supervisory institutions. Nevertheless, in Indonesia, the function of supervisory institution is still unbalanced. Police investigators and prosecutors are stationed at different institutions. The National Police Commission (Kompolnas -Komisi Kepolisian Nasional) and the Prosecutorial Commission (Komjak -Komisi Kejaksaan) are formed by Presidential Regulation, while the Judicial Commission as the Court supervisory institution is formed by the law. A comparison of France, The Netherlands, United Kingdom, and Russian reveals the fact that Police and Prosecutor are under the Ministry of Internal Affairs and the Ministry of Justice. Therefore, the coordination between investigators and prosecutors can be harmonious under one coordination. This study employed a comparison method to observe the supervisory institutions to minimize the practice of judicial corruption in the sub-system. There are two opportunities. The first is to strengthen the main tasks and authorities of Kompolnas and Komjak by changing the existed legislation or establishing new supervisory institution that covering all supervisory functions in the activities of investigation, prosecution, and examination (by the judge) in one legislation.
\end{abstract}

Keywords: external supervision, integrated criminal justice system, strengthening legislation.

\section{Lembaga Pengawasan Eksternal Penyidik dan Penuntut sebagai Bagian Integral dalam Sistem Peradilan Pidana (Studi Komparasi di Perancis, Inggris, Belanda Dan Rusia)}

\begin{abstract}
Abstrak
Dalam sistem peradilan pidana, terdiri dari sub-sub sistem yang menjalan tugas dan kewenangan yang berbeda, namun memiliki tujuan yang sama, yaitu melaksanakan ketentuan perundang-undangan untuk menanggulangi kejahatan. Sub sistem tersebut, diantaranya Kepolisian, Kejaksaan, Kehakiman dan Lembaga Pemasyarakatan. Namun praktik di Indonesia, bekerjanya sub-sub sistem tersebut tidak harmonis, sehingga kepastian hukum menjadi sesuatu yang langka. Salah satu faktor bekerja sub-sub sistem tersebut adalah adanya lembaga pengawasan, namun di Indonesia, lembaga pengawasan tersebut masih timpang. Penyidik polisi dan jaksa penuntut berada pada lembaga pengawasan yang
\end{abstract}

PADJADJARAN Journal of Law Volume 5 Number 3 Year 2018 [ISSN 2460-1543] [e-ISSN 2442-9325]

Associate Professor of the Faculty of Law, Pelita Harapan University, Gd. D, Lt 4, UPH Karawaci, Lippo Karawaci., agus.budianto@uph.edu, S.H., M.Hum. (Universitas Atma Jaya Yogyakarta)., Dr. (Universitas Pelita Harapan). 
berbeda, yaitu oleh Komisi Kepolisian Nasional (Kompolnas) dan Komisi Kejaksaan (Komjak) yang dibentuk dengan sebuah Peraturan Presiden, sedangkan untuk pengadilan diawasi oleh Komisi Yudisial yang dibentuk dengan Undang-Undang. Perbandingan yang didapat dari negara Perancis, Belanda, Inggris dan Rusia didapat fakta, bahwa Kepolisian dan Kejaksaan berada di bawah Menteri Dalam Negeri dan Kehakiman, sehingga koordinasi antara penyidik dan penuntut dapat harmonis karena berada di bawah satu koordinasi. Metode yang digunakan adalah melakukan perbandingan pada konteks lembaga pengawas dalam sub sistem peradilan pidana terpadu untuk meminimalisir praktik judicial corruption. Terdapat dua peluang, yaitu memperkuat tugas pokok dan kewenangan Kompolnas dan Komjak di perubahan perundang-undangan atau membentuk lembaga pengawasan baru dengan sebuah Undang-Undang dengan menggabungkan menjadi satu lembaga fungsi pengawasan pada kegiatan penyidikan, penuntutan dan pemeriksaan di pengadilan (oleh hakim).

Kata kunci: pengawasan eksternal, penguatan legislasi, sistem peradilan pidana terpadu.

\section{A. Introduction}

As stated in the first-year report (2013) of this study, two factors constraints law enforcement practice in Indonesia. The first is internal factor that cover human error and the second is external factors that include political and money pressure. Human error are the lack of integrity and the knowledge of law enforcement officers, either in the stages of investigation (police), prosecution (public prosecutor), judicial examination of case (trial judge), and implementation (correctional institution). The lack of integrity of law enforcement officers is also influenced significantly by the role of advocate, either directly or indirectly. Many advocates try to affect the criminal law enforcement process. Although the temptation of political offer and money pressure is high, a strong integrity of officers should be able to prevent or to counter it. Political pressure and money should not be an internal obstacle. ${ }^{1}$

In this regard, the direct impact of judicial mafia network does not affect Indonesian. However, indirectly, it can undermine the foundation of the rule of law that has been instilled by the founding fathers in the Indonesian Constitution. In addition, these practices can drive Indonesia to the bankruptcy and degenerate, and even accelerate, the damage of the judiciary process, which will escalate public antipathy. The public antipathy may lead into vigilante. For instance, an attempted murder of a judge who involved in corruption cases by an NGO activist.

From the findings of the first-year research, we narrowed down the discussion into the indicator number four: "the lack of internal control". ${ }^{2}$ In the Indonesian integrated criminal justice system, each institution has its own supervision agencies. The Police has General Supervision Inspector (Irwasum -Inspektur Pengawasan Umum) and the Division of Profession and Security (Propam -Profesi dan Pengamanan); the Attorney General has the Assistant Attorney General for

Agus Budianto, Delik Suap Korporasi di Indonesia, Bandung: Karya Putra Dharwati, 2011, p. 7.

See L. Maqutu, "When the Judiciary Flouts Separation of Powers: Attenuating The Credibility of The National Prosecuting Authority", Potchefstroom Electronic Law Journal, Vol. 18, No. 7, 2016. 
Supervision (Jamwas -Jaksa Agung Muda bidang Pengawasan); and the Supreme Court has the Assistant Chief Justice for Supervision and Development.

Theoretically, the definition of criminal justice system is the sustainability of subsystems that involved in the law enforcement. Therefore, every state has a criminal justice system with similar nature but also has unique character based on its social, society, culture, and politics conditions. The basic term of criminal justice system is a process carried out by State against people who violate the criminal law. Asshiddiqie states that, the judicial process without material law would be paralyzed. on the contrary, the judicial process without formal law would be wild and could lead to "judicial tyranny".

Cavadino and Dignan say that a criminal justice system is "A term covering all those institutions which respond officially to the commission of offences, notably the police, prosecution authorities and the court". In other words, a criminal justice system does not only cover one institution but it is related closely to several state law enforcement institutions. According to Feeney, the tasks of a law officer will have an impact to other law officers. Feeney says "...what once criminal justice agency does likely to affect and be affected by other agencies and... a detailed knowledge of the kinds of interactions that are likely to take is essential for undertaking system improvement...". Packer states that law offices are integrated in a criminal justice system and they cannot be separated. It means, the tasks of all law officers are interrelated.

Although good governance has been implemented, spirit of corps is the reason to free a law enforcement officer agency from bribery practice. ${ }^{3}$ In the era of institutional reform, there is a demand to start an external supervisory agency within law enforcement officer environment. The Police and Attorney General subsystem is handed over to National Police Commission and Prosecutorial Commission respectively based on the Presidential Decrees Number 18 of 2011 on Prosecutorial Commission of the Republic of Indonesia and Presidential Decree Number 17 of 2011 on National Police Commission. Both regulations, systematically, cannot be a foundation for both institutions since it they only rely on the Law Number 2 of 2002 on State Police of the Republic of Indonesia (State Police Law) and the Law Number 16 of 2004 on the Attorney General. Therefore, it is necessary to strengthen the legislations.

\section{B. Monitoring the Ideal of Criminal Justice System by Comparative Study}

The number of bribery cases, which occurs at stages of investigation, prosecution, and court examination show that the law-enforcement officers' awareness level does not fulfill people expectation. Various attempts and efforts by the internal agencies have been done to build accountable, transparent, systematic, and

Harkristuti Harkrisnowo, Menggugat Eksistensi Korban Dalam Sistem Peradilan Pidana di Indonesia, in Mardjono Reksodiputro, Kriminologi dan Sistem Peradilan Pidana: Kumpulan Karangan Buku Kedua, Jakarta: Department of Criminology University of Indonesia, Pusat Pelayanan Keadilan dan Pengabdian Hukum, 1997, p. 135. 
structured performance monitoring system. the formation of external supervisory agencies in an integrated criminal justice system is expected to strengthen the efforts. However, the practice of bribery in law enforcement process still occurs. This study aims to find a solution through a comparative study of integrated criminal justice system in France, the Netherlands, the United Kingdom, and Russia. The United Kingdom is selected because it is a common-law state that applies custom, legislation, and case law as its system's characteristics. On the other hand, the Netherlands and France apply civil law system. Russia, after the dissolution of Soviet Union, has made a fundamental change from the socialist to the continental law and Anglo-Saxon systems. Its law is based on the Constitution of the Russian Federation and the general principles of law that are recognized by international law.

\section{The Criminal Investigation and Prosecution System in France}

Criminal justice system in France is different from the one in Indonesia although both states adopt the civil law system. The French Police Investigator generally consists of (1) Judicial Police (handling cases), (2) Police Intelligence, (3) Police that deals with public safety, and (4) Border Police. There is also a squadron of the Republic for Security, which specifically aims to maintain security. French Judicial Police performs law enforcement duties associated with three categories of offense: (1) minor violations (contraventio) such as traffic violations; (2) secondary violations (delict/offense) such as theft, fraud, robbery; and (3) crime, such as murder, rape, and hostage-taking. The National Police handle $70 \%-80 \%$ of violations in France. There are two judicial police units: (1) territorial brigade unit (entire territory of France); and (2) a central unit that handles specific things, like counterfeit money. The judicial police units are classified based on the forms of crimes and crimenetworks. Gendarmerie National Police can perform task in a lesser degree. ${ }^{4}$

The Minister of Home Affairs directly appoints Chairman of the French National Police. In the structure of the French Police, there is IGPN (Inspection Générale De La Police Nationale), which equals to Irwasum in Indonesia. The main task of IGPN is to investigate active police officers and conduct audits and inspections of all police stations. All investigation conducted by IGPN is independent. In 2012, IGPN investigated against 32 police officers suspected of corruption. ${ }^{5}$ When a police officer commits an offense, the degree of error can be raised by one level. A contravention can be considered as an offense and it can be considered a crime. Investigation on officers who committed law offenses can lead to a prosecution in the court that is also used for all ordinary French citizens. The perpetrators can be put in the same prison with all citizens. In the matter of serious violations (rape,

Presented by Jerome Leonnet (the Vice of Inspector General of National Police), Commissioner David Chanteux (the Vice Director of Rule and Ethic Division), and Commissioner Raymond Darriet (Director of Investigation), on the Commission III of the Parliament during the working visit to France, on April 21 to 272013.

5 This is also strengthened by Ruth (Security Attache of the Embassy of France in Indonesia), on April 21, 2013 before the Commission III of the House of Representatives. 
drugs, murder, unjustified shooting), the process can be held up to three months, before brought to the court.

In the France criminal justice system, the Attorney General coordinates police in investigation process. The police directly contact the Attorney Office when they conduct an investigation. For contravention, prosecutor file a case to the court within 24 hours and while awaits for trial, suspect can be free. For offense and crime, a commissioner judge (Juge D'instruction) will first verify the feasibility of cases. A judge (JL:D -Juge Des Libertés Et De La Détention) will determine whether to continue the temporary arrest while the investigation takes place and to decide whether suspect can be released or not, depending on the evidence and the time limit that is based on crime. It may last up to 2-3 years before trial.

In addition to internal monitoring from their superior and IGPN, the Police also supervised by five external parties. They are the Ministry of Justice, the Attorney Office, the Freedom and Information Commission, the National Commission for Wiretapping (Commission Nationale De Contrôle Des Interceptions De Sécurité), the Ombudsman (Défenseur des droits), and the Parliament. The Parliament also acts as the police supervisory agency that interrogates the government. For instance, when police officers throw stones at demonstrators, ${ }^{6}$ the Parliament can ask the Minister of Home Affairs about the act. Subsequently, they will run investigation on the concerned officer. When conducting an investigation of moderate and severe crime, police can do wiretapping. In France, judges and prosecutors are under the coordination of the magistrate. ${ }^{7}$

\section{The Criminal Investigation and Prosecution System in the Netherlands}

There are similarities between the criminal justice systems of France and the Netherlands. The Minister of Justice is in charge of law enforcement. The Ministry of Judicial Office is responsible to regulate the Attorney General Office and the Police. The Minister is responsible to answer all questions from the Dutch Parliament. ${ }^{8}$ If the Parliament is not satisfied with the answers, the minister could be dismissed. In the Netherlands, ${ }^{9}$ local police have dual accountabilities. The local police are responsible to the mayor where his office is located in terms of financial and administrative. They are also responsible to the Minister of Justice in terms of law enforcement. In a case of unknown perpetrator, police leads. However, when there are more than one alleged perpetrators, police and prosecutors will together

Presented by Jean Jacques Guilet (National Assembly member) before the Commission III of the House of Representatives, during working visit to France on April 21 to 27, 2013.

7 Tom R. Tyler, Legitimacy and Criminal Justice: An International Perspective, New York: Russel Sage Foundation, 2007, p. 305.

$8 \quad$ Presented by Leo Vester (Senior Legal Adviser, Legislative Quality Policy, Department of Legislation and Legal Affairs), before the Commission III of the House of Representatives, during working visit to the Netherlands on May 13 to $18,2013$.

9 Peter Johan P Tak, Criminal Justice System in Europe: The Netherlands, Leiden: Martinus Nijhoff Publishers, 1993, pp. $200-243$. 
determine the prime suspect. Judges has the authority to bring experts to the court. It is to prevent any questionable objectivity of expert.

In the Dutch prosecution process, ${ }^{10}$ prosecutors and judges have the great discretion. They do not prosecute based on charges. Prosecutor can make an alternative instrument in law enforcement. The prosecutor, not only in the form of criminal punishment, can also propose in the form of fine. When no agreement can be made, the judicial process continues. However, when an agreement on the payment is made, the money shall be used to cover the government cost. In terms of policy, the Dutch criminal law refers to the law of mixtures, law enforcement, and covenants. ${ }^{11}$ In the Dutch criminal justice system, the Attorney General has special prosecutors that handle both criminal or civil cases. Prosecutor can also determine whether a case is viable for an appeal or not. In addition, the Attorney General cooperates with the Supreme Court chambers (criminal, civil, tax). In every room, staffs check document comprehensiveness. ${ }^{12}$

\section{The Criminal Investigation and Prosecution System in the United Kingdom}

The United Kingdom applies the Common Law system. It is often called the Case Law or the Precedent. ${ }^{13}$ The highest prosecutor is called the Crown Prosecutor Service. Police and serious crime units investigate cases, which is submitted to the CPS for approval to be filed or not. ${ }^{14}$ Although the CPS is a part of the police forces, and the CPS and the police closely cooperate, the CPS is independent and police investigators may ask for advice from CPS. However, police investigators had no obligation to follow any advices given by the CPS but it is highly recommended to be sure whether the case is worth to be prosecuted or not. Only the prosecutor can decide whether the case can be brought to the court. Judge only decides guilty or innocence. Judge decided whether there is a need to be released on bail or not. ${ }^{15}$ In British criminal justice system, the parties are the Ministry of Home Affairs, Prison House, Police, Prosecutor, the Ministry of Justice, and Probation Office. A Probation Officer is a person who supervises people who are released under a bail or someone who has been returned to the community after serve in the prison.

10 Presented by Prof. Gerard Strijards (Public Prosecution Service of the Netherlands), before the Commission III of the House of Representatives during working visit to the Netherlands on May 13 to 18, 2013.

11 Presented by F. Pinar Olcer, the Dean of Faculty of Law - Leiden University, before the Commission III of the House of Representatives during working visit to the Netherlands on May 13 to 18, 2013.

12 Presented by Mr. Y. Buruma (Chief Justice) in the Supreme Court / Hoge Raad, before the Commission III the Commission III of the House of Representatives during working visit to the Netherlands on May 13 to 18, 2013.

13 Barda Nawawi Arief, Perbandingan Hukum Pidana, $1^{\text {st }}$ edition, Jakarta: PT. Raja Grafindo Persada, 1998, p. 47.

14 Presented by Anthony Salma, Prosecutor Specialist at the Crown Prosecution Service (CPS), before the Commission III of the House of Representatives during working visit to the United Kingdom, on April 28 to May 03, 2013.

15 Presented by His Honour Brian Barker QC, Senior Judge at the Criminal Court of England, before the Commission III of the House of Representatives during working visit to the United Kingdom, on April 28 to May 03, 2013. 
The CPS has five (5) main function: ${ }^{16}(1)$ to provide advice to police; (2) to review cases brought by the Police to CPS; (3) to determine whether the prosecution can be done, except in small cases; (4) to prepare materials for the court; and (5) to be a prosecutor in the court. The CPS strongly emphasizes the importance of reviewing the case, the process of evidence collection, and analysis of evidence so that they can build a strong prosecution. For instance, in a case of murder when the victim is not satisfied with the decision, then there will be face-to-face sessions between victims and prosecutors. If the victim is not satisfied, then there will be a judicial review to a higher court to determine whether the process is flawed or not. In this mechanism, there are certain levels when a decision is taken on the lower level of perceived unfit, then the senior director can ask for an investigation or a review of the case before judicial review. The key is transparency and cooperation.

\section{The Criminal Investigation and Prosecution System in Russia}

Russian Criminal Procedure is implemented based on the Code of Criminal Procedure and the Constitution of the Russian Federation in addition to the principles and norms of international law and international agreements, which have been ratified by the Russian government. Even if an international agreement made by the Government of the Russian Federation is contrary to the Criminal Code, the provisions of the agreement can be applied. The purpose of criminal proceeding is to protect the legal rights and interests of people and organizations who suffered from a criminal offense and to protect a person who allegedly committed the crime, which threaten rights and freedom. The Code of Criminal Procedure of the Russian Federation recognizes settlement outside the court (afdoening buiten process). ${ }^{17}$ It is regarded as one of the manifestations of the principle of fast, low cost, and simple judicial process. The principle of opportunity is globally defined as "The public prosecutor may decide conditionally or unconditionally to make prosecution to the court or not". Article 25 of the Code of Criminal Procedure of the Russian Federation states that the mild case or serious criminal acts could be overseen when there has been a peace with compensation between the suspect and the victim. According to Article 76 of the Criminal Code of the Russian Federation, a crime, either mild or serious, is a criminal offense with maximum sentence of 10 years in prison. Russian Code of Criminal Procedure recognizes private prosecution. Through private prosecution, victim can ask judicial trial directly, without going to investigator or prosecutor. This happens usually for mild cases, such as humiliation, mild persecution, or fraud. Courtroom trial can be lead by a single judge or a panel of judges, may lead criminal justice. The criminal proceedings must be carried out within a reasonable period and based on the Criminal Code of Russia. The process of criminal justice, actions and decisions are not to degrade the honor or to insult or to

16 Great Britain Parliament, House of Commons, Justice Committee, The Crown Prosecution Service: gate keeper of the Criminal Justice System, Britain: Stationery Office, 2009, pp. 100- 105.

17 Presented by Valery M. Lebedev (Chief Justice of the Russia Federation), before the working visit of the Commission III of the House of Representatives to Russia on April 14 to 19, 2013. 
threaten the safety of perpetrator. In other words, no one in the criminal justice process shall experience violence, torture, or other types of cruelty, humiliation, and demeaning. ${ }^{18}$

\section{Comparison Value between Countries}

Based on the exposition above, France has different police investigators for minor violations, secondary violations, and serious crimes. The Police institution is under the Ministry of Internal Affairs. Police works together with the Attorney Office to do investigation. However, for a secondary violations and crime, the Commissioner Judge is involved in the investigation process. In the Netherlands, Police institution and The Attorney Office are under the Ministry of Justice. Therefore, the police always cooperate with the Attorney Office since the beginning. The same system also happens in the UK where the Crown Prosecutor Service coordinates and cooperates with the police's serious crime unit in an investigation. In the Russian Federation, the Police Department is under the Ministry of Home Affairs. They have a law enforcement function together with the Prosecutor/Attorney General.

In Indonesia, Police institution is arranged by the State Police Law. The police institution is responsible directly to the President. The Attorney General is arranged by the Law Number 16 of 2004 on Attorney General of the Republic of Indonesia (Indonesian Attorney Law). It is also responsible directly to the President. The Police Institution and The Attorney General Office are two independent institutions. The relationship between both of them in the tasks of law enforcement is limited to preadjudication process. It means that the coordination starts when the police give the investigation examination result and evidences for the prosecution by an attorney (often called with P-19). The sectoral ego in each institution causes a weak coordination. ${ }^{19}$

On the other hand, the police institution has an agency that supervise members of the police, the Kompolnas. The prosecutors have Komjak as the supervision agency. However, both Komjak and Kompolnas do not have the authority to conduct a criminal investigation against members of police and public prosecutors when they violate their tasks. The authority only covers the investigation and the results should be handed over to the Chief of the police and the Attorney General.

The description clearly shows that there is a need to compare the criminal justice systems in France, England, the Netherlands and the Russian Federation related to the position of Police investigators and prosecutors. it is necessary to escalate a coordination for both law enforcement agencies to determine the evidences and to decide whether an investigation result will be prosecuted or not. The weakness of coordination so far is regarded as "a very harmful to justice seekers". Since it is the important stage, the new pattern in Indonesia is when an

18 Presented by Minyazeva Tatiana, the Head of Law School in People's Friendship University of Russia (RUDN), on the Commission III DPR RI working visit to Russia on 14 to 19 April 2013.

19 Bastian, "Tinjauan Yuridis Hubungan Fungsional Antara Penyidik dan Penuntut Umum Dalam Proses Pemeriksaan Perkara Pidana", Jurnal Ilmu Hukum Legal Opinion, $2^{\text {nd }}$ edition, Vol. 2, 2014, pp. 16-17. 
investigation is started and announced to the prosecutor, the prosecutor gives instructions. However, it is not when the case file is finished drawn up by the investigator. The instructions could be orally, SMS, telephone, e-mail. In France, the Attorney Office is always ready for a call from the investigators as the initiation of investigation and gives direct instructions. Therefore, the Indonesian government needs to think about this attorney system that will always be ready to give instruction like in the Netherland. This will help investigators to make contact. A small case does not need to be notified to prosecutor for an investigation and the Attorney Office only gives guidance for serious cases or difficult normative evidence. Furthermore, with the public prosecutor system that can add the evidences and witnesses when the trial started, the case file is not the most important matter now because in principle the vindication occurs in court. ${ }^{20}$

\section{Strengthening External Monitoring Legislation}

As stated above, the Indonesia's concept of the criminal justice system is different from the concept of criminal justice system in France, the UK, and Russia. The crucial difference is that the Police and the Attorney Office are mostly under one institution, namely the Ministry of internal Affairs. In France and the UK, the role of prosecutors is to monitor and to coordinate the police. In Indonesia, the investigators and prosecutors are in two different institutions, although both are equally responsible to the president.

Indonesia, France, UK, and the Netherlands has internal and external controls over police and prosecutor. In France, the control is executed by five external agencies. In Indonesia, the Parliament can also supervise the Police performance based on the Law Number 17 of 2014 on People Consultative Assembly for the tasks of (1) budget; (2) legislation; and (3) supervision. Commission III of the Indonesian House of Representatives that is in charge for law, human rights, and Security supervises performances of police, prosecutor, and the judiciary. However, the Parliament's supervision on the performance of the criminal justice system has not been maximized and has indirect access to the source of problem.

Heads of law enforcement agencies are more likely to cover up cases involving negligence and violations of law and/or code of conduct of the subordinates because if the case is brought in an open hearing in the Parliament, the stake is the credibility and reputation. Moreover, when it is published into the media, it will adversely affect the reputation of institution.

Therefore, in addition to surveillance field, the Parliament also (by legislation) forms external agencies that have strong authority to carry out supervisory function in Indonesian criminal justice system. In this case, Commission III of the Indonesian House of Representatives has strengthened the Prosecutorial Commission and the 20 Ministry of Justice of the Republic of Indonesia, "Academic Paper of Criminal Procedure Draft Law of 2014",
unpublished, p. 13. 
National Police Commission in the new draft of the Indonesian National Police Commission Law (2013), which is currently discussed in the legislation.

\section{E. The Position of External Supervisory Commission in the Amendment of Law 1. Draft of Amendment of the Indonesian Police Law}

The amendment of State Police Law is an initiative of the Parliament in the National Legislation Program (2014), along with 69 other drafts. Currently, the discussion and the academic paper has already been in the Parliament legislative bodies. The Amendment of the State Police Law is to shift the police paradigm, from the perspective of state police to civilian police. Civilian police means to be close and associated with community, honest, disciplined, polite, friendly, not arrogant, and do not abuse the powers. Based on the grand strategy of the Police (2005-2025), by this time, the police should have passed the stage of trust building, and should have entered into partnership. However, the police public service and public expectations and trust on police are still low. This is resulted from the weak enforcement on the law that is based on the human rights principles.

The existence and authority enforcement of the National Police Commission that are set in the new draft of the State Police Law indicate some problems. First, the National Police Commission is still not comparable or equivalent with the organization of Police it supervises. The National Police Commission possess the authority to conduct investigations on police's violations of the law and/or codes of conduct. However, it has no authority to execute investigation to the Chief of Police, only in the form of recommendations. Despite the existence National Police Commission is arranged in the State Police Law, the establishment of the institution, as well as the duties and authorities, are stipulated in the Presidential Decree (vide Presidential Decree Number 17 of 2011). The Chief of Police is directly responsible to the President, while the head of National Police Commission is responsible to the President through the Coordinating Minister for Political, Legal, and Security Affairs as an ex officio member and Chairperson of the National Police Commission (indirectly responsible to the president). Hence, the concept arranges the National Police Commission as the Non-Ministry State Institutions. ${ }^{21}$

Based on the concept, the House of Representatives as the initiative for the amendment of the State Police Law, together with the National Police Commission and the Prosecutorial Commission, create a draft that can be used as a discussion agenda on the draft. The National Police Commission proposes several amendments as follows.

1. Article 1 (15): The Institution of National Police (hereinafter LKN, Lembaga Kepolisian Nasional) is an independent National Institution under the President.

2. Article 8 (6): The Police training is conducted by the Chief of Police under the coordination with LKN.

21 As stipulated in the Law Number 39 of 2008 on the Ministry of State, that the National Police Commission be placed as a Non-Ministry Government Agency-Article 25 paragraph (1) and (2). 
3. Article 38 (1): the LKN functions as: (b) functional supervisory agency for the functional order of Indonesian National Police

4. Article 39: the authority of $\operatorname{LKN}(\mathrm{d})$ : to supervise and to evaluate the performance and conduct of Police officers, which then will be used as a recommendation to the Chief of Police. (e): to accept, to continue, to clarify, and to investigate any public complain regarding performance or conduct of police, then passing it on to the chief of police, as well as to accept and to evaluate the completion report. (f): Investigate the alleged ethical and/or abuse of power conducted by police officers (cold cases); (I): In the event of any discontinued process on alleged disciplinary, ethical code, and criminal violations by police members, the LKN recommends the chief of police to perform a disciplinary trial and/or ethical trial, and legal criminal proceedings.

As an independent Institution, The National Police Commission provides recommendation on Police leadership candidates, direction of the policy, and supervise a better and independent Police.

\section{Draft of Amendment of Indonesian Attorney Law}

The House of Representatives' Plenary Session, April 12, 2012, decided four initiative of Parliament new drafts of Law, one of which is a draft to amend the Indonesian Attorney Law. Based on the Decree of the House of Representatives Number LG.01.01/04140/DPR/IV/2012 dated April 20, 2012, which commissioned the Commission III of House of Representatives to a discussion on the drafting of the Indonesian Attorney Law, the Prosecutorial Commission is formed and appointed with the duties and authority that are based on the Indonesian Attorney Law. Article 38 states that to improve the performance quality of the attorney office, the President may establish a commission with the arrangement and the authority governed by the President". Furthermore, institution, composition, duties, and authority of the Prosecutorial Commission is stipulated in the Presidential Regulation Number 18 of 2011 on Prosecutorial Commission of the Republic of Indonesia. Until now, the discussion of the Draft of Amendment of Indonesian Attorney Law is still in the Commission III of House of Representatives, which deals with institutional strengthening and authority of Prosecutorial Commission, placed in Chapter III (A), Articles 37 (A) to 37 (I). Some substances to empower the position and the authority of the Prosecutorial Commission are, among others, as follows.

1. Article 37 (D): Prosecutorial Commission has the authority to: (a) keep and uphold the attorney honor, dignity, and behavior; (b) establish a code of ethics and/or Attorney General and prosecutor's code of conduct; and c) maintain and enforce the implementation of prosecutor's code of ethics and/or code of conduct.

2. Article 37 (E) (1): In preserving and upholding the dignity, honor, and code of conduct of Attorney Office, the Prosecutorial Commission follows the Attorney's code of ethics and/or code of conduct;

3. Article 37 (E) (1) (c): Receive public report regarding the Attorney's code of ethic and/or behavior; (d): Verify and investigate (in private) any alleged attorney's 
ethical and behavioral violations; (e): Validate the report on alleged attorney's ethical and/or behavioral violations; and (f): Take legal action and/or other measures against those individuals, groups of persons, or legal entity that are degrading the honor and dignity of the Attorney;

4. Article 37 (E) (4): To reserve and uphold the dignity, honor, and conduct of the Attorney Office, the Prosecutorial Commission shall request law enforcement officials to conduct wiretaps and recorded conversations in the case of alleged violation of the code of ethics and/or code of conduct of Attorney; (5): Law enforcement officials shall follow up the requests from the Prosecutorial Commission referred to in (4); (6): In the case of alleged violation of the code of ethics and/or code of conduct, the Prosecutorial Commission proposes application of sanctions to the Attorney General for prosecutor who allegedly violate; and (7): Attorney General impose sanctions against prosecutor who violate the code of ethics and/or code of conduct proposed by the Prosecutorial Commission within sixty days from the date the proposal is received.

5. Article 37(F) (1) and (3): (1) in the case where the Attorney General has not imposed sanctions within the period referred to in Article 37(E) (7), the Prosecutorial Commission's proposal is automatically applied and must be implemented by the Attorney General; (2) In the event of disagreement between the Prosecutorial Commission and the Attorney General on the Commission's proposal for imposing sanctions on Attorney referred to in Article $37(E)(6)$, there will be a joint examination of the Prosecutorial Commission and the Attorney General on concerned prosecutor; and (3) in the case of the Attorney General and the Prosecutorial Commission within the period referred to in Article 37(E) paragraph 7 do not reach an agreement as referred to in paragraph 2, the Commission's proposal that meet the provisions in Article 37(E)

(6) is automatically applied and must be conducted by the Attorney General.

Based on the results of focus group discussion, which were held within the framework of strengthening the results of this second-year study, as well as based on the statement of one of the Attorney Commissioner members (Komjak), the reinforcement as exists in Presidential Regulation Number 18 of 2011 is enough.

\section{F. The Position of External Control Commissions in a Separate Law}

There is an expectation from the National Police Commission leaders to strengthen the position, duties, and authority of the Commission in a separate law. The new draft is called the National Police Institution Law. The idea is based on the strategic role of the institution in an open, accountable, and professional law enforcement, regardless the task of proposing the National Police leadership candidates and the direction of policy. In order to carry out supervisory duties in the field of law enforcement, the National Police Commission feels that it is necessary to be equal with the police institution. This is related to the weaknesses of the tasks of the National Police Commission, which always face obstacles from the officers of the National Police in requesting data and information from the National Police, government agencies, the community and/other parties deemed necessary. 
While the authority to receive suggestions and complaints, National Police Commission can perform the following activities: receiving and forwarding suggestions and complaints to the police for further action; ask and/or with the Police to follow up on suggestions and complaints; clarify and monitor the process and follow up on the advice of the people who made the complaints; follow the case, a disciplinary hearing and the hearing of the Commission Police Professional Code of Conduct; and following examination of the alleged breach of discipline and code of ethics for the members/police officer.

The weak role of the National Police Commission is very different compared to the role of the National Police Commission of Northern Ireland, for instance. There is Police Ombudsman, which is an independent. It is to receive complaints, conduct investigations, and report findings to the police. In addition, France has five institutions that perform the police supervision. Brig. Pol. (ret) Syafriadi Cut Ali states that the functional supervisory of the National Police Commission is not yet maximized in monitoring and assessing the performance of officers of police. It is related to the strength of the jurisdiction of the National Police Commission. Andrianus Meliala mentions the same idea that the Amendment should add one to two chapters/articles to the existing Police Law that cover, first, the Police Supervision (ranging from politics to finance operations), and second, the National Police Commission as both external and internal supervisory body.

The second proposal is that, in the future, the police is positioned under the Ministry of Police or the Ministry of Internal Security (depending on the elected president) with a choice of (a) a Non-Portfolio Ministry (State Ministry) or (a) Portfolio Ministry (a Ministry similar to the Ministry of Defense). The third proposal is to create a new law where the National Police Commission serves as a performance supervisory agency with the options to be a public complaint board (like in the USA and the UK), or as the police authority (like in Japan, New Zealand, and the UK), or both (the unique Indonesian model).

\section{G. Conclusion}

In principle, the weakness of tasks and authorities of the National Police Commission and Prosecutorial Commission are caused by many factors. As a result, the supervisory function in law enforcement as an integrated criminal justice system is not optimal yet. This study focused on the weak duties and functions. They are caused by weak legislations of National Police Commission and Prosecutorial Commission. The conclusion of this second-year study is to strengthen the position and the authority of these two agencies. Nevertheless, it is not the case for the authority of the Judicial Commission, which is already equal with the Supreme Court as the highest judiciary, or the advocate profession that is still handled by the Honor Council as stipulated in the Law of Advocate Profession.

To be able to create a model or format of an ideal criminal justice system, this study compared the systems of France, the Netherlands, the UK, and Russia. In France, the Netherlands, and the UK, the Institution of Police and Attorney are positioned under the Minister of the Interior Affairs, which leads to the harmonious 
coordination between investigators and prosecutors. Indonesia has an independent Police supervisory agency. The French Police has internal supervisory agency and, also, supervised by five institutions. In the Netherlands, police have two accountabilities: for the administration and budget to the mayor, and to the Minister of Justice in terms of law enforcement. In the UK's legal system, CPS has five main functions. Through this agency, victim can directly bring prosecution into trial, without the involvement of investigator or prosecutor.

To strengthen position and authority of the National Police Commission and Prosecutorial Commission in national legislation, this study offers two formulas. The first is to strengthen legislation in the draft of amendment to the Law of Police and the Law of Prosecutor. Despite the National Police Commission and the Prosecutorial Commission are directly responsible to the President, the Law Number 39 of 2008 on State Ministries regulates that the Coordinating Minister for Law and Security is the ex officio Chairman and members of the Commissions. The second is the enforcement of legislation in the draft of amendment. In this case, the draft that has been prepared is the draft of State Police Institution to replace the Presidential Decree Number 17 of 2011 on the National Police Commission.

\section{H. Acknowledgment}

This project was conducted with the support of the 2013/2014 Research Grant from the Ministry of Research, Technology, and Higher Education of the Republic of Indonesia. The Research Program Agreement was released in the Letter of Assignment Number 007/K3.KMN/SPK/2013 and is based on the Research Grants Agreement for Lecturer of the Private University Coordinator in budget year 2014 Number 186/K3/KM/2014, dated May 7, 2014. We have formulated a solution to strengthen the legislation of the external supervisory agencies in the integrated criminal justice system to decrease corruption.

For their generous help and support, I would like to express the deepest appreciation to Jerome Leonnet, the Vice of Inspector General IGPN (Inspector Générale de la Police Nationale), Commissioner David Chanteux (the Vice Director of Rule and Ethic Division), and Commissioner Raymond Darriet (Director of Investigation), Mr. Ruth (Security Attaché of the Embassy of France in Indonesia), Mr. Jean-Jacques Guilet (the National Assembly member), Leo Vester (Senior Legal Adviser, Legislative Quality Policy, Department of Legislation and Legal Affairs), Prof. Gerard Strijards (Public Prosecution Service of the Netherlands), Pinar Olcer (the Dean of Faculty of Law - Leiden University), Mr. Y. Buruma (Chief Justice of the Supreme Court/Hoge Raad), Anthony Salma (Prosecutor Specialist at the Crown Prosecution Service -CPS), and His Honour Brian Barker QC (Senior Judge at the Criminal Court of England).

\section{References}

Books

Agus Budianto, Delik Suap Korporasi di Indonesia, Karya Putra Dharwati, Bandung, 2011. 
Barda Nawawi Arief, Perbandingan Hukum Pidana, $1^{\text {st }}$ edition, PT. Raja Grafindo Persada, Jakarta, 1998.

Great Britain Parliament, House of Commons, and Justice Committee, The Crown Prosecution Service: gate keeper of the Criminal Justice System, Stationery Office, Britain, 2009.

Mardjono Reksodiputro, Kriminologi dan Sistem Peradilan Pidana: Kumpulan Karangan Buku Kedua, Department of Criminology University of Indonesia, Pusat Pelayanan Keadilan dan Pengabdian Hukum, Jakarta, 1997.

Tak, Peter Johan P, Criminal Justice System in Europe: The Netherlands, Martinus Nijhoff Publishers, Leiden, 1993.

Tyler, Tom R., Legitimacy and Criminal Justice: An International Perspective, Russel Sage Foundation, New York, 2007.

\section{Other Documents}

Bastian, "Tinjauan Yuridis Hubungan Fungsional Antara Penyidik dan Penuntut Umum Dalam Proses Pemeriksaan Perkara Pidana", Jurnal IImu Hukum Legal Opinion, $2^{\text {nd }}$ edition, Vol. 2, 2014.

Maqutu, L., "When the Judiciary Flouts Separation of Powers: Attenuating the Credibility of The National Prosecuting Authority", Potchefstroom Electronic Law Journal, Vol. 18, No. 7, 2016.

Ministry of Justice of the Republic of Indonesia, "Academic Paper of Criminal Procedure Draft Law of 2014", unpublished.

\section{Legal Documents}

Law Number 2 of 2002 on State Police of the Republic of Indonesia [Undang-Undang Nomor 2 Tahun 2002 tentang Kepolisian Negara Republik Indonesia].

Law Number 16 of 2004 on Attorney General [Undang-Undang Nomor 16 Tahun 2004 tentang Kejaksaan Republik Indonesia].

Law Number 39 of 2008 on State Ministries [Undang-Undang Nomor 39 Tahun 2008 tentang Kementerian Negara].

Law Number 17 of 2014 on People Consultative Assembly [Undang-Undang Nomor 17 Tahun 2014 tentang Majelis Permusyawaratan Rakyat].

Presidential Decrees Number 17 of 2011 on National Police Commission [Peraturan Presiden Nomor 17 Tahun 2011 tentang Komisi Kepolisian Nasional].

Presidential Decrees Number 18 of 2011 on Prosecutorial Commission of the Republic of Indonesia. [Peraturan Presiden Nomor 18 Tahun 2011 tentang Komisi Kejaksaan Republik Indonesia].

Code of Criminal Procedure of the Russian Federation.

\section{Interviews}

Anthony Salma, Prosecutor Specialist at the Crown Prosecution Service (CPS). Commissioner David Chanteux (the Vice Director of Rule and Ethic Division).

F. Pinar Olcer, the Dean of Faculty of Law - Leiden University.

His Honour Brian Barker QC, Senior Judge at the Criminal Court of England. 
Jean-Jacques Guilet (the National Assembly member of France).

Jerome Leonnet (the Vice of Inspector Générale de la Police Nationale).

Leo Vester (Senior Legal Adviser, Legislative Quality Policy, Department of Legislation and Legal Affairs).

Minyazeva Tatiana (the Head of Law School in People's Friendship University of Russia-RUDN).

Mr. Ruth (Security Attaché of the Embassy of France in Indonesia).

Prof. Gerard Strijards (Public Prosecution Service of the Netherlands).

Valery M. Lebedev (Chief Justice of the Russia Federation).

Y. Buruma (Chief Justice) in the Supreme Court / Hoge Raad. 